\title{
Kopi bagi Kita
}

\author{
Fathurozi \\ Staf Balai Penelitian dan Pengembangan Agama Semarang
}

Ngopi dulu biarenggak gila". Ungkapan itu kadang kita dengar di kalangan anak muda yang kerap nongkrong di kedai kopi, angkringan, kafe, dan lainnya di daerah Jawa Tengah dan Jawa Timur. Seolah minum kopi menjadi jaminan bagi kita untuk tidak depresi atau mengalami kerumitan hidup yang memusingkan. Sejatinya, ia sekadar untuk minum kopi. Ajakan yang mengisyaratkan tradisi minum kopi jauh lebih nyaman jika dilakukan bersama (kolektif) ketimbang sendirian. Ngopimemiliki fungsi sosial: mengakrabkan, menghangatkan pergaulan.

Tradisi minum kopi biasa dilakukan masyarakat setiap pagi. Sebagian menambahkannya pada malam hari ketika begadang atau tugas ronda. Namun, sekarang kopi tak lagi sekadar tradisi, tetapi menjadi rutin, atau kebutuhan sehari-hari, menjadi teman aktivitas sejak pagi hingga dini hari. Bahkan, hampir umum di setiap penyelenggaraan acara formal, juga informal, yang dilaksanakan pihak pemerintah ataupun swasta, selalu menyelipkan satu acara khusus: coffee break.

Ngopi pun sudah menjadi gaya hidup. Tak hanya jadi pengakrab. Dengan minum kopi bersama orang bisa mendapatkan inspirasi atau jalan keluar dari masalah sehari-hari, di kantor, rumah tangga, pergaulan, dan sebagainya.

Dalam dunia film, adegan minum kopi hampir selalu terselip. Sekitar 1986, film yang berjudul Damai Kami Sepanjang Hari, dibintangi oleh Iwan Fals, diceritakan bagaimana keharmonisan keluarga ditunjukkan dengan tiap pagi Iwan dibangunkan untuk menikmati secangkir kopi.

\section{Budaya kopi}

Sebagaimana tradisi galibnya, ia kemudian menjadi bagian dari kebudayaan secara keseluruhan, budaya Indonesia. Budaya ini pertama kali dilakukan saat Pemerintah Belanda menerapkan sistem tanam paksa. Kopi pertama kali tumbuh di dataran tinggi Sumatera Utara, dekat Danau Toba pada 1888, diikuti dataran tinggi Gayo (Aceh) dekat Danau Laut Tawar pada 1924.

Pada 1850, Edward Douwes Dekker alias Multatuli, menulis sebuah buku yang berkait dengan kultur kopi di Jawa, berjudul Max Havelaar and the Coffee Auctions of the Dutch Trading Company. Lebih dari masalah kopinya, buku ini membelalakkan publik di Kerajaan Belanda akan betapa tragis nasib penduduk pribumi Nusantara dan betapa biadab kebijakan kolonial Kerajaan Belanda di Hindia Belanda. Sungguh bertolak belakang dengan apa yang ada dalam budaya Belanda.

Pada 1920, perusahaan-perusahaan kecil di Indonesia mulai menanam kopi sebagai komoditas utama. Perkebunan di Jawa dinasionalisasi pada hari kemerdekaan dan direvitalisasi dengan varietas baru kopi arabika pada 1950-an.Tak ayal, sekarang 
warung di pinggir jalan hingga hotel berbintang menawarkan kopi. Bahkan, elite partai politik melakukan lobi-lobi politik sambil menikmati secangkir kopi.

Menurut sejarah, coffee break pertama kali dilakukan pada 1880 di perusahaan TG Mandt Wagon Co, perusahaan yang mempekerjakan perempuan di sekitar pabrik. Perempuan yang bekerja diberi kopi agar bisa bekerja maksimal. Namun, ada yang mengatakan coffee break baru terjadi sekitar 1907, saat seorang pemilik pabrik, Luigi Bezzera, menemukan mesin espresso.

Dalam dunia seni, kopi adalah sumber inspirasi yang tiada habisnya. Banyak film yang diproduksi berangkat dari tradisi atau budaya itu. Sementara dalam dunia musik, sejumlah lagu diciptakan dengan menyebut kopi sebagai bagian inti syairnya, seperti lagu "Secangkir Kopi" (Jony Iskandar), "Kopi Susu" (Mansyur S), "Kopi Dangdut" (Fahmi Shahab), dan "Join Kopi" (Blackout).

Bahkan, banyak penulis buku juga mengupas dunia kopi. Ada buku Geng Kopi Tubruk karya Ruslan (2006), Filosopi Kopi karya Dee (2006), Kopi Merah Putih: Obrolan Pahit Manis Indonesia karya Isman H Suryaman (2009), Teman Minum Kopi: Sebuah Kumpulan Essay Kehidupan Dari Manca Negara karya Zara Zettira ZR and Friends (2006), Secangkir Kopi Untuk Sahabat Customer karya Cyltamia Irawan (2010), dan Secangkir Kopi Segunung Pahala, Lely Suraiya (2004).

Ada buku kopi lain yang menarik dari Prabu Revolusi berjudul Secangkir Kopi Inspirasi (2013). Penulisnya mengutip pendapat seorang ulama, Sayyid Habib Umar bin Saqqaf dalam kitabnya, Tafrihul Qulub wa Tafrihul Kurub, yang menyatakan, "Kopi memang hitam, tapi menyalakan semangat, bahkan memancarkan cahaya." Artinya, agama pun seolah melegitimasi peran, fungsi, dan kedudukan sosial ngopi.

Maka, mungkin benar juga, kita merasa aneh, bisa jadi "gila juga", kalau belum ngopi. Gila di sini tentu saja bukan sebuah gejala psikis atau semacam penyakit mental. Tapi, kan, banyak juga orang gila di pentas politik atau bisnis, misalnya, yang tidak selalu merujuk pada kesehatan mentalnya.

Dimuat Kompas, 29 Maret 2016

http://print.kompas.com/baca/2016/03/29/Kopi-bagi-Kita 